\title{
Composition peculiarities and origin of Lherzolitic Abnormal Composition pyropes (evidence of Siberian platform lithospheric mantle evolution)
}

\author{
N. Tychkov, N. Pokhilenko, S. Kuligin, E. Malygina. \\ Institute of Geology and Mineralogy, Novosibirsk, Russian Federation
}

Perennial searching works on the Siberian platform have shown in its different parts multiple kimberlite bodies of different ages. Most intense manifestations of kimberlite magmatism are: $\mathrm{D}_{3}-\mathrm{C}_{1}$ (367-345 Ma), $\mathrm{T}$ (245-215 Ma), $\mathrm{J}_{3}$ (160-149 Ma). This work is based on mantle derived material from different age kimberlites from Siberian platform, which let us argue a problem of lithospheric mantle composition and structure changes through time.

Our researches have allowed to mark out the group of Lherzolitic Abnormal Composition pyropes (LACpyropes) and to describe this group as separate paragenetic type which is widespread on Siberian platform (Pokhilenko et al., 1999; Tychkov et al., 2008) as well as in other regions (Kopylova et al., 2000; Griffin et al., 2002).

The aim of this investigation is to understand LACpyropes genesis and also to give explanation of drastic pyropes average composition change in Mesozoic Siberian kimberlites comparative to those of Paleozoic time.

Specific composition of LAC-pyropes. In addition to the anomalous position on the paragenetic discrimination diagram $\mathrm{Cr}_{2} \mathrm{O}_{3}-\mathrm{CaO}$ (higher content of $\mathrm{Ca}$ ), the LAC pyropes differ from pyropes of other genetic types in having a higher content of $\mathrm{FeO}$, a lower content of $\mathrm{MgO}$, virtually no $\mathrm{TiO}_{2}$ and $\mathrm{Na}_{2} \mathrm{O}$, and a higher content of $\mathrm{MnO}$. It is known that the content of $\mathrm{Mn}$ increases with $\mathrm{Ca}$ in coexisting clinopyroxene. The content of $\mathrm{Ca}$ in lherzolites is controlled by the enstatite component in clinopyroxene and depends on temperature. According to experimental data (Brey and Kohler, 1990), the content of $\mathrm{MnO}$ considerably increases as temperature drops (from 0.25 to $0.5 \mathrm{wt} \%$ with T decreasing from 1200 to $900{ }^{\circ} \mathrm{C}$, at 30 and $40 \mathrm{kbar}$ ). The LAC pyropes are mostly enriched in $\mathrm{MnO}$ (usually $>0.4$ wt.\% (Tychkov et al., 2008)), and coexisting clinopyroxenes, in CaO, which evidently indicates a relatively low-temperature character of the association. Lower contents of $\mathrm{TiO}_{2}$, $\mathrm{Na2O}$, and, according to our investigations and literature data (Kopylova et al., 2000; Kuligin et al., 2000), other trace incompatible elements such as $Y$, $\mathrm{Zn}, \mathrm{Zr}$, and $\mathrm{Sr}$ in LAC pyropes are not typical of such "very fertile lherzolite [that] may have been subjected to Fe metasomatism" (after Griffin et al., 2002). The LAC pyropes have also lower contents of REE and an S-shaped profile of REE pattern distribution, which is typical of depleted lherzolites and harzburgites.

Pyropes of this kind were also mentioned in publications before. On the basis of similarity between compositions of LAC pyropes and pyropes from pyroxenites and, in particular, from the similar position of the $\mathrm{Cr}_{2} \mathrm{O}_{3}-\mathrm{CaO}$ diagram trend, (Pokhilenko et al., 1999) suppose a genetic relationship between pyroxenites and LAC-pyrope-bearing rocks. This hypothesis is confirmed by numerous findings of complex xenoliths containing lherzolites (clinopyroxene-bearing harzburgites) and pyroxenites in immediate contact (Kuligin et al., 2000). These xenoliths are especially abundant in the pipes of the northeastern Siberian Platform, e.g., in the Obnazhennaya pipe.

By the example of pyropes from the Jerico pipe, Kopylova (Kopylova et al., 2000) states that the LACgroup pyropes belong to the spinel-bearing peridotites and, using the calculated spinel-garnet equilibrium in the system, argues that this fact is responsible for the abnormal position of the trend of these pyropes on the $\mathrm{Cr}_{2} \mathrm{O}_{3}-\mathrm{CaO}$ diagram. The main argument for this supposition is that in the Jerico pipe almost all of the pyropes from xenoliths of spinel-bearing garnet peridotites belong to the trend typical of the LACpyropes. However, this rule does not always work for the LAC pyropes from kimberlites in other regions, e.g., in the Udachnaya pipe (Tychkov et al., 2008).

A complex study of more then 30 xenoliths, which contain LAC-pyropes, and also data from literature, let us argue about LAC-pyropes origin. All the rocks bearing LAC-pyropes belong to protogranular peridotites without traces of shearing. On average they consist of olivin (80\%), orthopyroxene (12\%), pyrope (6\%). As a rule, amount of clinopyroxene is low (2\%), not exceeding few per cent in volume (but there are no rocks bearing LAC-pyropes without clinopyroxene as a phase).

Though actually pyropes belong to the lherzolite 
paragenesis, their trend on the $\mathrm{Cr}_{2} \mathrm{O}_{3}-\mathrm{CaO}$ diagrams corresponds also to compositions of pyroxenites or verlites. For the sake of brevity, the pyropes under study will be called "Lherzolitic Abnormal Composition pyropes” (LAC-pyropes).

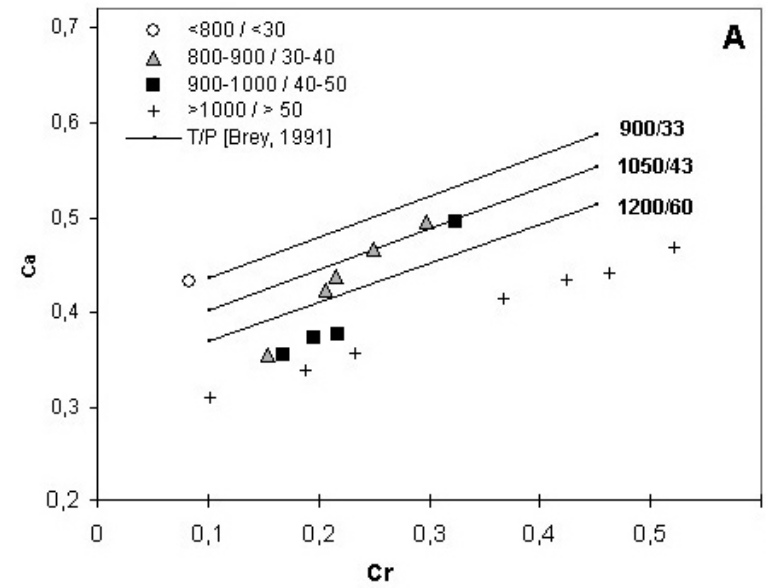

Fig.1. Cr and Ca ratios (f.u.) in pyropes from xenoliths from Jerico pipe (Kopylova et al., 2000) and calculated $T\left({ }^{\circ} \mathrm{C}\right)$ and $P$ (kbar) (Brey and Kohler, 1990). Lines experimental data of Brey (1991).

PT calculations (Brey and Kohler, 1990) show, that LAC-pyropes bearing rocks belong mostly to middle and upper horizons of the vertical section of the lithosphere mantle. $P T$ conditions in such xenoliths do not exceed $4,0 \mathrm{GPa}$ and $1000^{\circ} \mathrm{C}$ in most cases (Udachnaya pipe).

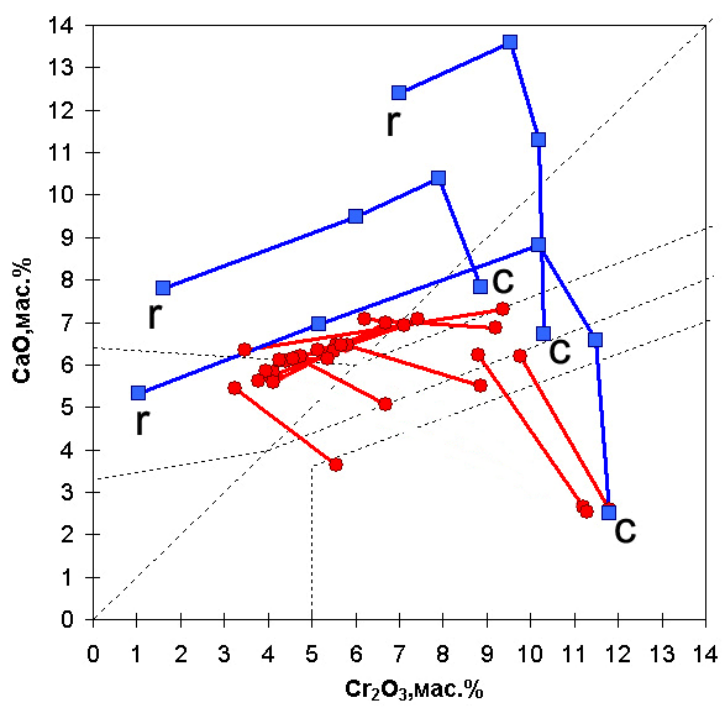

Fig.2. Change of pyrope compositions on $\mathrm{Cr}_{2} \mathrm{O}_{3}-\mathrm{CaO}$.

Some features of pyrope composition depend not only on the rock composition but also on PT conditions of its existence. This follows from experimental data on natural systems (Brey and Kohler, 1990). The data show that for the lherzolite paragenesis the amount of $\mathrm{CaO}$ in pyrope, which is actually in equilibrium with clinopyroxene, depends on temperature and/or pressure (see fig.1). Probably, that is pressure. That follows from multiple foundations of high-titanium pyropes

(from shared lherzolites), which correspond to a high-calcium $\mathrm{Cr}_{2} \mathrm{O}_{3}$-CaO trend in low-depth pipes of Siberian platform outer parts (Aldan shild (Ashepkov et al. 2001)).

Our own and literature data suggest that LAC-pyropesbearing rocks may appear as a result of secondary enrichment of low-depth harsburgite-dunite suit after reequilibration of garnet with neogenic clinopyroxene. That follows from multiple foundations of xenoliths where not zonal pyropes significantly differs from each other in composition within a xenolithe (Udachnaya pipe, see Fig. 2, red dots). It is not quite clear yet, how much of LAC-pyrope-bearing rocks appeared that way.

LAC-pyropes distribution in Siberian kimberlites of different ages. Average part of LAC-pyropes in paloozoic kimberlites is $6,9 \%$ (6,1\% for NE part of a platform). In Triassic kimberlites it increases to $13,4 \%$ and in Jurassic - up to 33,4\%. Increase of LACpyrope-bearing rocks amount in litospheric mantle could be a result of two reasons: lithosphere thinning and/or change of rocks composition after secondary enrichment.

Figure 3 illustrates of LAC-pyropes amount vs. diamonds amount in Siberian kimberlites.

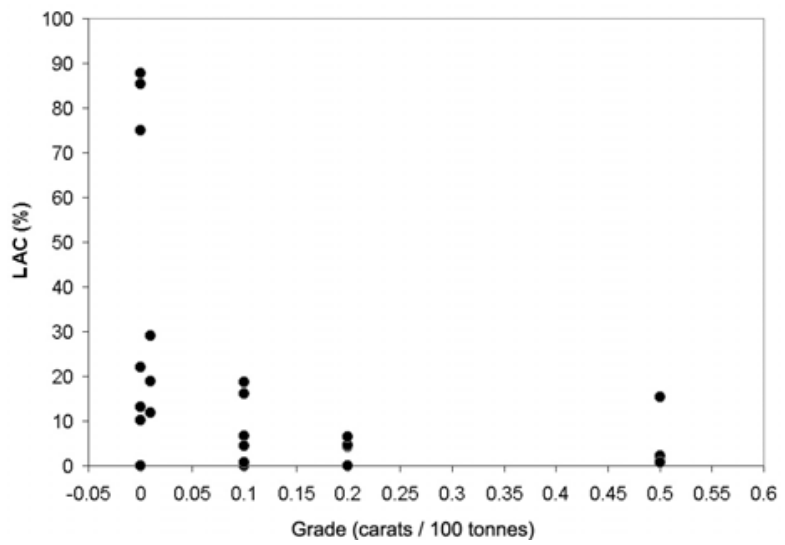

Fig.3 LAC-pyropes amount vs. diamonds amount in Siberian kimberlites

In Siberian kimberlites of different ages we have also studied distribution of high-titanium pypopes, which belonges to shared high-temperature lherzolites (G1type after Dawson and Stephens (1975) scheme or L13, L27 after (Griffin et al., 2002) scheme). There is a clear difference of $\mathrm{G} 1$-pyropes trends on $\mathrm{Cr}_{2} \mathrm{O}_{3}-\mathrm{CaO}$ diagram observed in Mesozoic kimberlites in compare to Paleozoic. It is convenient to represent position of such trends on $\mathrm{Cr}_{2} \mathrm{O}_{3}-\mathrm{CaO}$ diagram as a correlation of $\mathbf{a}$ and $\mathbf{b}$ coefficients, which are the coefficients of an approximating line equation $(\mathrm{y}=\mathbf{a x}+\mathbf{b})$ of G1-pyropes trends. Thus, shifting of these trend (and of approximating line) toward higher Ca content will tent $\mathbf{a}$ and $\mathbf{b}$ coefficients to grow (Fig.4). 


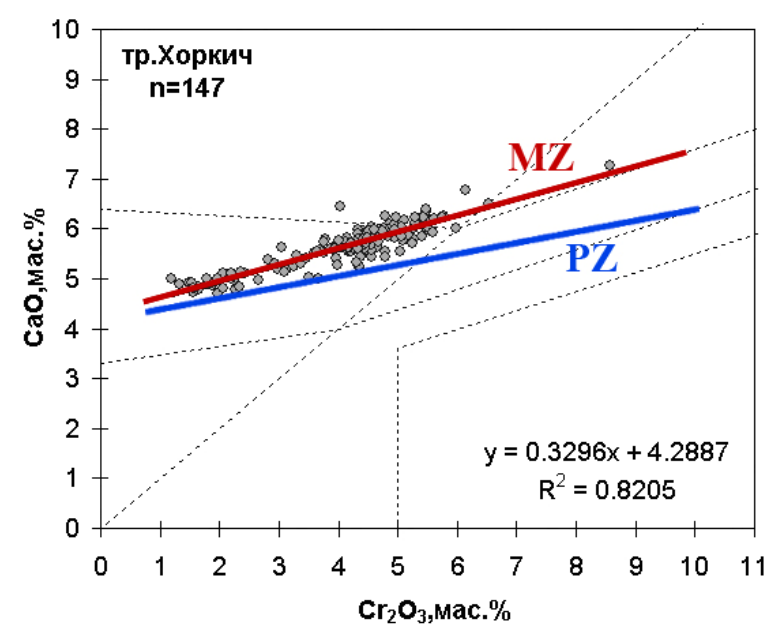

Fig. 4. G1-pyropes trends on $\mathrm{Cr}_{2} \mathrm{O}_{3}-\mathrm{CaO}$ diagram.

It is generally known, that this rocks, that contain G1pyropes appear after secondary enrichment of depleted rocks in lithosphere-asthenosphere transition zone. Taking into account experimental data of (Brey and Kohler, 1990) (Fig.1) and our investigations, we can establish a fact, that $\mathbf{a}$ and $\mathbf{b}$ coefficients of G1-pyrope trends grow with decreasing of lithosphere thickness.

Figure 5 clearly shows, that $\mathbf{a}$ and $\mathbf{b}$ coefficients of G1pyrope trends for Mesozoic kimberlites are much higher, than from Paleozoic. This tendency is present also on the SW part of a platform, where Paleozoic diffusive haloes of kimberlitic minerals and Mesozoic kimberlites (Triassic) exist on the same territory. A drastic change of G1-pyrope trend from PZ to MZ time displays a considerable lithosphere thinning in this region too (Fig. 5).

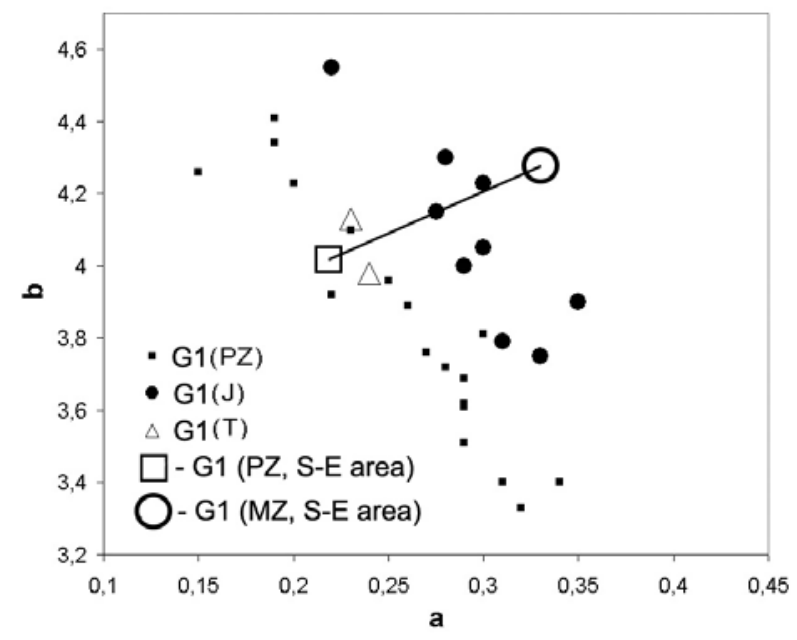

Fig.5. Distribution of G1- pyropes compositions in Siberian kimberlites.

A paleogeotherm peculiarity (Pokhilenko et al., 1999), LAC-pyropes distribution and changes of G1-pyropes trends position among kimberlites and diffusive haloes of different ages on a Siberian platform show considerable lithosphere thinning of its N-E side and drastic increase of rock part characterized by LACpyropes from Paleozoic to Mesozoic time in this region. Our field works carried out in last years revealed a LAC-pyropes host-rocks abundantly presented in lithospheric mantle of the Central part of a platform (Tychkov et al., 2008).

These facts, together with shown essential change of lithospheric thickness in S-W platform side in the time between Paleozoic and Mesozoic manifestations of kimberlite magmatism, suggest that Perm-Triassic Siberian plume influence gave rise to a considerable change of the lithospheric mantle composition and structure in different parts of the platform.

Brey G.P., Kohler T., 1990. Geothermobarometry in four phase lherzolites I: experimental results from 10 to $60 \mathrm{~kb}$. Journal of Petrology V.31, pp. 1313-1352

Pokhilenko N.P. Sobolev N.V. Kuligin S.S. Shimizu N. et al Peculiarities of distribution of pyroxenite paragenesis garnet in Yakutian kimberlites and some aspects of the Siberian craton lithospheric mantle// 7th International Kimberlite Conference: Proceedings. - Cape Town, 1999. v.2. p. 689-698.

Kuligin, S.S., Malkovets V., Pokhilenko N.P., Vavilov M., Griffin W., O’Reilly S. Mineralogical and geochemical characteristic of a unique mantle xenolith from the Udachnaya kimberlite pipe.// 8th International Kimberlite Conference: Ext. Abstr., 2000.

Kopylova M.G., Russell J.K., Stanley C. Cookenboo H.Garnet from Cr- and Ca-saturated mantle: implications for diamond exploration // Journal of Geochemical Exploration 68 (2000) 183-199

Ashepkov I.V., Vladykin N.V., Gerasimov P.A. Saprykin A.I., Khmelnikova O.S., Anoshin G.N. Petrology of disintegrated deep xenoliths of Chompoline field pipes (Aldan shield) // Alkaline magmatism and issues of mantle sources - Irkutsk, 2001. p. 187-212 (In Russian).

Griffin W.L., Fisher N.I., Friedman J.H., O’Reilly S.Y., Ryan C.G. Cr-pyrope garnets in the lithospheric mantle 2. Compositional populations and their distribution in time and space. Geochemistry Geophysics Geosystems, 2002. V. 3, N. 12.

Tychkov N.S., Pokhilenko N.P., Kuligin S.S. and Malygina E.V. Composition and origin of peculiar pyropes from lherzolites: evidence for the evolution of the lithospheric mantle of the Siberian Platform. Russian Geology and Geophysics. Volume 49, Issue 4, April 2008, Pages 225-239. 